\title{
Treatments for child and adolescent victims of sexual violence: are they effective?
}

\author{
Averdijk, Margit
}

\begin{abstract}
Sexual violence among children and adolescents can have detrimental consequences. This article presents a brief overview of the current international knowledge base on the effectiveness of treatment programs for child and adolescent victims of sexual violence. Overall, treatment programs show moderate to large beneficial effects on victims' well-being. Treatments that have a longer duration and shorter sessions are more effective than other treatments. Some of the challenges include that few victims receive treatment and that a considerable number of prior studies does not meet the standards for thorough effectiveness research.
\end{abstract}

DOI: https://doi.org/10.1515/pubhef-2018-0136

Posted at the Zurich Open Repository and Archive, University of Zurich ZORA URL: https://doi.org/10.5167/uzh-181300

Journal Article

Published Version

Originally published at:

Averdijk, Margit (2019). Treatments for child and adolescent victims of sexual violence: are they effective? Public Health Forum, 27(1):47-49.

DOI: https://doi.org/10.1515/pubhef-2018-0136 
Margit Averdijk*

\section{Treatments for child and adolescent victims of sexual violence: are they effective? Behandlungen für Opfer von sexueller Gewalt gegen Kinder und Jugendliche: Sind sie wirksam?}

https://doi.org/10.1515/pubhef-2018-0136

\begin{abstract}
Sexual violence among children and adolescents can have detrimental consequences. This article presents a brief overview of the current international knowledge base on the effectiveness of treatment programs for child and adolescent victims of sexual violence. Overall, treatment programs show moderate to large beneficial effects on victims' well-being. Treatments that have a longer duration and shorter sessions are more effective than other treatments. Some of the challenges include that few victims receive treatment and that a considerable number of prior studies does not meet the standards for thorough effectiveness research.
\end{abstract}

Keywords: child sexual abuse; psychosocial intervention; sexual abuse; sexual abuse victims; sexual victimization; sexual violence.

Zusammenfassung: Sexuelle Gewalt bei Kindern und Jugendlichen kann sehr schädliche Folgen haben. Dieser Artikel bietet einen kurzen Überblick über die derzeitige internationale Wissensbasis über die Wirksamkeit von Behandlungsprogrammen für Kinder und Jugendliche, die Opfer sexueller Gewalt sind. Insgesamt zeigen Behandlungsprogramme mäßige bis große positive Auswirkungen auf das Wohlbefinden der Opfer. Behandlungen mit einer längeren Dauer und kürzeren Sitzungen sind wirksamer als andere Behandlungen. Zu den Herausforderungen gehört unter anderem, dass nur wenige Opfer behandelt werden und eine beträchtliche Anzahl von früheren Studien nicht den Standards für eine gründliche Wirksamkeitsforschung entspricht.

Schlüsselwörter: psychosoziale Intervention; sexuelle Gewalt; sexuelle Missbrauchsopfer; sexuelle Viktimisierung; sexueller Kindesmissbrauch; sexueller Missbrauch.

*Correspondence: Margit Averdijk, PhD, Jacobs Center for Productive Youth Development, University of Zurich, Andreasstraße 15, Zurich 8050, E-mail: margit.averdijk@jacobscenter.uzh.ch
Introduction

Sexual violence affects an important minority of children and adolescents. It is estimated that around $8 \%$ of males and $15-20 \%$ of females are the victim of sexual violence in childhood and adolescence worldwide [1-3]. This includes sexual violence committed by peers, dating partners, parents, and other adults.

Sexual violence against children and adolescents can be severely traumatizing. Victims experience a range of negative consequences, such as internalizing problems (e.g. unhappiness and fear) and externalizing problems (e.g. fighting and aggression) [4, 5]. They also display more mental, personality, and major affective disorders [6].

Providing victims with support is essential for paving the way towards positive development and well-being. In this article, I briefly discuss evidence showing that treatment programs for child and adolescent victims of sexual violence have moderate to large beneficial effects on their well-being. However, the effectiveness of programs depends on such factors as the treatment type and duration.

\section{Programs}

Treatment programs for child and adolescent victims of sexual violence have varying formats. Some follow a standardized format but others not, making it challenging to provide a general overview. Treatments may take place in various settings, including mental health facilities, hospitals, juvenile detention centers, group homes, schools, and at home. Many programs are delivered by highly qualified and specialized mental health professionals.

The types of treatment include, for example, eye movement desensitization reprocessing, group therapy, psychodynamic therapy, or improvement of the child's self-reliance. Play and art therapy are often used when treating younger children.

Often used programs are cognitive behavioral treatments, such as trauma-focused cognitive behavioral 
therapy (TF-CBT). TF-CBT focuses on distorted views, reactive emotions and behavior (e.g. anger, fear), and interactions in the child's family. Treatment for (nonoffending) caregivers can also be provided. TF-CBT typically includes 12-18 sessions of 50-90 min duration. This therapy is less appropriate for children and youths who display very serious effects of sexual victimization [www.childwelfare.gov]. TF-CBT can be used alone or combined with other treatments.

\section{Effectiveness}

At least 10 overview studies have evaluated the effectiveness of treatments for child and adolescent victims of sexual violence (e.g. [7-9]). Overall, they show moderate to large beneficial effects on victims' well-being [10-13]. These findings seems to apply to internalizing problems, post-traumatic stress disorders (PTSD), externalizing problems, self-esteem, and social functioning.

There is evidence that these effects hold or slightly increase over time. Research suggests that the effects hold for 6 to at least 21 months [14-16].

For TF-CBT specifically, findings have been somewhat mixed. Some studies show that it is especially effective, alone or in combination with supportive therapy or psychodynamic treatment (e.g. play therapy), (e.g. [16]). Other studies show that TF-CBT is similarly effective as other therapies or only more effective for some symptoms and less so for others [10].

\section{Factors that influence effectiveness}

Overview studies show that not all treatments have the same effects. First, research generally shows that treatments that last longer (i.e. more weeks) or include a larger number of sessions are more effective than shorter treatments.

Second, some studies have shown that shorter treatment sessions ( $1 \mathrm{~h}$ or shorter) have larger effects than longer sessions.

Third, it is currently largely unclear whether group or individual therapy has more desirable effects. Some evidence suggests that individual therapy may be more effective for PTSD in particular, but another study found similar effects of individual and group therapy for other symptoms. Family therapy may also be effective, but more studies are needed.

\section{Recommendations}

There is consistent evidence that psychological treatment for child and adolescent victims of sexual violence can reduce the negative effects of victimization. This points to the importance of psychological therapy in helping victims recover. There are nevertheless challenges when it comes to assessing the effectiveness of these treatments as well as their implementation. Drawing conclusions from evaluations is not always easy, as they often do not fulfill the necessary requirements for scientific evaluation. It is recommended that longterm randomized controlled trials are designed to answer questions as to the effectiveness of treatments.

Another major challenge is that only a small part of victims receive treatment. For example, in Switzerland, only $4 \%$ of adolescent victims of sexual violence received psychological or psychiatric treatment [17]. Initiatives to better reach victims therefore seem of critical importance.

\section{Author Declaration}

Author contributions: The author has accepted responsibility for the entire content of this submitted manuscript and approved submission. Funding: Underlying initial research was supported by the Swiss Ministry of Social Insurances and the Child Protection Fund. Conflict of interest: The author states no conflict of interest. Ethical statement: Primary data for humans nor for animals were collected for this research work.

\section{Autorenerklärung}

Autorenbeteiligung: Die Autorin trägt die Verantwortung für den gesamten Inhalt dieses Artikels und hat der Einreichung des Manuskripts zugestimmt. Finanzierung: Das zugrunde liegende Forschungsprojekt wurde finanziert von dem Schweizerischen Bundesamt für Sozialversicherungen und dem Schweizerischen Fonds für Kinderschutzprojekte. Interessenkonflikt: Die Autorin erklärt, dass kein wirtschaftlicher oder persönlicher Interessenkonflikt vorliegt. Ethisches Statement: Für die Forschungsarbeit wurden weder von Menschen noch von Tieren Primärdaten erhoben.

\section{References}

1. Barth J, Bermetz L, Heim E, Trelle S, Tonia T. The current prevalence of child sexual abuse worldwide: a systematic review and meta-analysis. Int J Public Health 2013;58:469-83.

2. Pereda N, Guilera G, Forns M, Gómez-Benito J. The prevalence of child sexual abuse in community and student samples: a metaanalysis. Clin Psychol Rev 2009;29:328-38. 
3. Stoltenborgh M, Van ljzendoorn MH, Euser EM, BakermansKranenburg MJ. A global perspective on child sexual abuse: meta-analysis of prevalence around the world. Child Maltreat 2011;16:79-101.

4. Chen LP, Murad MH, Paras ML, Colbenson KM, Sattler AL, Goranson EN, et al. Sexual abuse and lifetime diagnosis of psychiatric disorders: systematic review and meta-analysis. Mayo Clinic Proc 2010;85:618-29.

5. Paolucci EO, Genuis ML, Violato C. A meta-analysis of the published research on the effects of child sexual abuse. J Psychol 2001;135:17-36.

6. Spataro J, Mullen PE, Burgess PM, Wells DL, Moss SA. Impact of child sexual abuse on mental health: prospective study in males and females. Br J Psychiat 2004;184:416-21.

7. Corcoran J, Pillai V. A meta-analysis of parent-involved treatment for child sexual abuse. Res Soc Work Pract 2008;18:453-64.

8. Macdonald G, Higgins JP, Ramchandani P, Valentine JC, Bronger LP, Klein P, et al. Cognitive-behavioural interventions for children who have been sexually abused. Cochrane Database Syst Rev 2012;14:CD001930.

9. Silverman WK, Ortiz CD, Viswesvaran C, Burns BJ, Kolko DJ, Putnam FW, et al. Evidence-based psychosocial treatments for children and adolescents exposed to traumatic events. J Clin Child Adoles Psychol 2008;37:156-83.

10. Hetzel-Riggin MD, Brausch AM, Montgomery BS. A meta-analytic investigation of therapy modality outcomes for sexually abused children and adolescents: an exploratory study. Child Abuse Negl 2007;31:125-41.
11. Peltonen K. Efficacy of interventions for sexually abused children-a literature review and meta-analysis of treatment of post traumatic stress symptoms. Int J 2014;2:11.

12. Reeker J, Ensing D, Elliott R. A meta-analytic investigation of group treatment outcomes for sexually abused children. Child Abuse Negl 1997;21:669-80.

13. Skowron E, Reinemann DH. Effectiveness of psychological interventions for child maltreatment: a meta-analysis. Psychother Theor Res Pract Train 2005; 42:52.

14. Taylor JE, Harvey ST. Effects of psychotherapy with people who have been sexually assaulted: a meta-analysis. Aggress Violent Behav 2009;14:273-85.

15. Trask EV, Walsh K, DiLillo D. Treatment effects for common outcomes of child sexual abuse: a current meta-analysis. Aggress Violent Behav 2011;16:6-19.

16. Sánchez-Meca J, Rosa-Alcázar Al, López-Soler C. The psychological treatment of sexual abuse in children and adolescents: a meta-analysis. Int J Clin Health Psychol 2011;11:67-93.

17. Averdijk M, Mueller-Johnson K, Eisner M. Sexual victimization of children and adolescents in Switzerland. Final report for the UBS Optimus Foundation. Zurich, Switzerland: UBS Optimus Foundation, 2011.

Article Note: This paper presents an updated version of chapter 22 in Averdijk M, Eisner M, Luciano E, Valdebenito S, Obsuth I. Wirksame Gewaltprävention. Eine Übersicht zum internationalen Wissensstand. 2014. 